\title{
MOŽNOSTI NADALJNJEGA SONARAVNEGA RAZVOJA OB TREH SOSEDNJIH JUŽNOALPSKIH REKAH: PIAVI, TILMENTU IN SOČI
}

\author{
Karel Natek ${ }^{*}$
}

Izvleček

UDK 556.53:551.3(282)

Članek prinaša glavne rezultate primerjalne študije o treh južnoalpskih rekah (Piavi in Tilmentu v Italiji ter Soči v Sloveniji), ki so si po naravnih značilnostih zelo podobne, zaradi različne rabe pa se po možnostih nadaljnjega sonaravnega razvoja med seboj zelo razlikujejo, saj sta Piava in Tilment skoraj v celoti izrabljena za pridobivanje električne energije, Soča pa je ostala $v$ razmeroma naravnem stanju.

Ključne besede: Soča, Piava, Tilment, sonaravni razvoj, geomorfologija, rečna struga, rečni sistem

THE POSSIBILITIES OF SUSTAINABLE DEVELOPMENT IN THE RIVER BASINS OF THE THREE ADJACENT SOUTHERN ALPINE RIVERS: PIAVE, TAGLIAMENTO AND SOČA

\section{Abstract}

The paper presents some results of the comparative study of three neighboring Alpine rivers (Piave and Tagliamento in Italy and Soča in Slovenia) with considerable similarities in natural characteristics but rather different in the possibilities of future development. The Italian rivers are both exploited for the production of electricity, the Soča River is preserved in pretty natural condition what could be considered as a good opportunity for the future sustainable development of the whole river basin.

Key words: Soča, Piave, Tagliamento, sustainable development, geomorphology, river bed, river system

\footnotetext{
${ }^{*}$ Dr., doc., zasebni raziskovalec, Trnovski pristan 8, 1000 Ljubljana, Slovenija.
} 


\section{UVOD}

V razmeroma podobnem svetu Južnih apneniških Alp imamo štiri gorske reke, ki iz pretežno apnenčastega in dolomitnega visokogorskega sveta tečejo proti jugu $\mathrm{V}$ Jadransko morje (Brenta, Piava, Tilment in Soča). Čeprav so si med seboj zelo podobne, so med njimi velike razlike, tudi glede možnosti nadaljnjega razvoja dolinskega sveta ob njih. S primerjalno analizo treh rek (Piave, Tilmenta in Soče) lahko opredelimo njihove značilnosti in stvarno ocenimo njihov širši, alpski in evropski pomen. Iz te primerjave je jasno razvidna izjemna vrednost Soče, kajti na obeh njenih sosedah na italijanski strani meje sta zgrajena hidroenergetska sistema za pridobivanje vršne energije.

Piava (italijansko Piave; $220 \mathrm{~km}$ ) izvira v Karnijskih Alpah ob vznožju Monte Peralba $(2693 \mathrm{~m})$ in teče najprej skozi slikovito alpsko pokrajino Cadore med Dolomiti na zahodu in Karnijskimi Alpami na vzhodu, nato po 1--2 km široki dolini do Belluna in prek Beneške ravnine proti Jadranskemu morju. Na njej so po drugi svetovni vojni zgradili velik hidroenergetski sistem s 7 akumulacijskimi jezeri in 8 hidroelektrarnami, tako da je $\mathrm{v}$ večjem delu alpskega toka $\mathrm{v}$ široki strugi le skromen 'ekološko sprejemljiv minimalni pretok'. Ker hidroenergetski sistem proizvaja predvsem dragoceno vršno energijo, so na zajezitvenih jezerih zelo velika nihanja vodne gladine, tako da so s turističnega vidika povsem neuporabna. V dolina Piave je turizma malo, razen nekaj manjših zimskošportnih središč v zgornjem delu (Cima Sappada, Sappada).

Naslednja reka proti vzhodu je Tilment (Tagliamento; $170 \mathrm{~km}$ ) s pritokom Bela (Fella; 50 km), ki izvira v Karnijskih Alpah vzhodno od Pieve di Cadore in teče proti vzhodu do sotočja z Belo pri Pušji vasi (it. Venzone), nato pa ostro zavije proti jugu v Furlansko nižino. Zaradi pridobivanja električne energije je rečna struga bolj ali manj brez vode, saj že v povirnih grapah preusmerijo večino vode po podzemnih cevovodih v akumulacijska jezera (Enciclopedia ..., 1. del, 1971, s. 381).

Soča $(139 \mathrm{~km})$ je najvzhodnejša alpska reka, ki teče $\mathrm{v}$ Jadransko morje. Izvira $\mathrm{v}$ osrčju Julijskih Alp, teče sprva po ozki alpski dolini (Trenta in Soča), nato skozi tektonsko udorino Bovške kotline, po ozki dolini med Žago in Kobaridom in nato vse do Tolmina po 1--2 km široki dolini $\mathrm{z}$ obsežnimi prodnimi terasami na obeh bregovih.

\section{PRIMERJALNA ANALIZA PIAVE, TILMENTA IN SOČE}

Vse tri reke tečejo po apnenčasto-dolomitnem svetu Južnih apneniških Alp in s povirji ne segajo v kristalinske Osrednje Alpe. Izrazito modrozeleno barvo vode ima zlasti Soča, medtem ko se je ta pri Piavi in Tilmentu izgubila zaradi 
hidroenergetskega izkoriščanja. Za porečje Soče je nadalje značilna še močna zakraselost površja, tako da velik del soške vode prihaja iz kraških izvirov (med drugimi Izvir Soče, Boka, Glijun), denudacijski procesi na pobočjih pa so šibkejši kot $\mathrm{v}$ porečjih Piave in zlasti Tilmenta, kjer je večji delež erozijsko manj odpornih dolomitnih kamnin.

V primerjavi z ostalima rekama je Soča nad akumulacijskih jezerom pri Mostu na Soči zelo dobro ohranjena. Ker je velika večina alpskih rek regulirana ali energetsko izkoriščena, je naravna ohranjenost Soče izjemno pomembna za celotni alpski prostor, saj v celih Alpah ni nobene druge tako velike, a tako lepo in sklenjeno ohranjene reke. Glede tega se Tilment in Piava z njo sploh ne moreta primerjati, saj so od njunega naravnega toka ostala le obsežna, z vrbovjem zaraščajoča se prodišča in večji del časa zelo majhen vodni pretok, ki ne omogoča niti normalnega delovanja vodnega ekosistema niti rekreacijsko-turistične rabe.

V dolini Piave je sicer samo akumulacijsko jezero Pieve di Cadore (48,0 mil. m3 vode), v katerem vodna gladina niha za približno 8 metrov, medtem ko so ostale akumulacije v stranskih dolinah, večinoma zelo visoko nad glavno dolino, med drugim v dolini Ansiei pri Santa Catarini (5,5 mil. m3 vode), v dolini reke Boite nad krajem Valle di Cadore (3,18 mil. m3), na reki Mae pri Forno di Zoldo (0,9 mil. m3), $\mathrm{v}$ dolini Gallina nad Soverzenejem (5,9 mil. m3) ter zloglasno jezero Vajont nad Longaronejem s predvideno prostornino $150 \mathrm{mil}$. $\mathrm{m} 3$.

Delovanje hidroenergetskega sistema na Piavi je zaradi vršne energije sicer zelo pomembno, vendar pa katastrofa 9. oktobra 1963, ko je velik skalni podor zasul jezero Vajont, vodni val pa uničil mesto Longarone ob Piavi (umrlo je 2018 ljudi), ter občasno zelo hitro spreminjanje pretoka opozarjata na stalno grožnjo in negotovost, povezano z življenjem v dolini.

Tudi vode zgornjega dela porečja Tilmenta so izkoriščene za pridobivanje električne energije v HE Ampezzo in Somplago, kamor jih dovajajo po dolgem omrežju predorov (Enciclopedia ..., 2. del, 382). Zgornji del Tilmenta je za razliko od doline Soče nad Bovško kotlino tudi težko dostopen, zaradi močnih erozijskih procesov nevaren in turistično neprivlačen. V srednjem toku je pod Tolmezzom reka obdana $\mathrm{s}$ protipoplavnimi nasipi, ki naselja na obrobju doline varujejo pred hudourniškimi poplavami, ponekod več kot kilometer široko rečno korito pa ni posebno privlačno zaradi nesorazmerno širokih prodišč in majhnih vodnih pramenov, ki se med njimi dobesedno izgubijo.

Ta del Tilmenta je sicer podoben strugi Soče v Bovški kotlini, vendar pa je ta veliko bolj privlačna zaradi manjših, bolj raznolikih prodišč in močnejših vodnih pramenov, do $60 \mathrm{~m}$ visoke ježe bovške terase tik nad strugo Soče in slikovitega visokogorskega obrobja. 
Pri Guminu (it. Gemona) vstopi Tilment v približno $8 \mathrm{~km}$ široko čelno kotanjo tilmentskega ledenika, ki jo od Furlanske nižine ločijo 30--50 m visoki morenski nasipi. Za razliko od Soče, kjer je prehod iz visokogorskega v sredozemski svet zelo počasen in poteka $\mathrm{v}$ številnih stopnjah vse od Bovca navzdol, je ob Tilmentu ta prehod zelo hiter in zaradi tega tudi manj pokrajinsko raznolik.

Železna dolina (it. Val di Ferro) ob Tilmentovem pritoku Beli med Tabljo (it. Pontebba) in izlivom v Tilment se po privlačnosti lahko kosa s soško dolino, vendar pa je zaradi izrazite prometne vloge močno degradirana. Za množice turistov iz Severne in Srednje Evrope, ki drvijo proti Sredozemskemu morju, je to sicer privlačen del poti, na katerem pa niti ni nobenega počivališča.

Čeprav je tudi Soča prava hudourniška reka $\mathrm{z}$ več kot 100-kratno razliko med najnižjim in najvišjim pretokom, se od ostalih dveh rek razlikuje po sledečih značilnostih:

1. lahka dostopnost na krajevni ravni (t.j. dostopnost rečne struge) in hkrati odmaknjenost od velikih, tranzitnih prometnih poti;

2. naravni vodni tok in rečna struga vse do akumulacijskega jezera pri Mostu na Soči z minimalnimi vodnogospodarskimi posegi;

3. pestrost geomorfnih oblik v rečni strugi in velika spremenljivost vodnega toka na kratke razdalje;

4. tesna prepletenost naravnih in kulturnih elementov pokrajine;

5. razmeroma velik vodni pretok tudi v poletnih mesecih in neonesnažena voda, kar omogoča različne oblike rekreacije in športni ribolov.

Primerjalna analiza treh rek vključuje glavne značilnosti, ki so pomembne za razmišljanje o nadaljnjem sonaravnem razvoju. Ker so to po svojem bistvu vrednote, jih je kvantitativno zelo težko opredeliti, sicer pa je v ospredju iskanje tistega, zaradi česar je Soča po mnenju večine nekaj posebnega v celotnem alpskem prostoru. 
Tabela 1: Primerjava nekaterih značilnosti Piave, Tilmenta in Soče.

\begin{tabular}{|c|c|c|c|}
\hline & Piava & Tilment & Soča \\
\hline Dostopnost pokrajine (1 = najlažja) & 2 & 1 & 3 \\
\hline Neposredna dostopnost reke s ceste $(1$ = najlažja $)$ & 2 & 3 & 1 \\
\hline Slikovitost širše okolice (1 = največja) & 2 & 3 & 1 \\
\hline Slikovitost dolinskega dna $(1=$ največja $)$ & 2 & 3 & 1 \\
\hline Vključenost reke v kulturno pokrajino (1 = največja) & 2 & 3 & 1 \\
\hline Ohranjenost kulturne pokrajine $(1=$ največja $)$ & 2 & 3 & 1 \\
\hline Stopnja aktivnega vzdrževanja kulturne pokrajine $(1=$ največja $)$ & 1 & 3 & 2 \\
\hline Gostota poselitve doline (1 = najmanjša $)$ & 3 & 1 & 2 \\
\hline Stopnja urbaniziranosti doline $(1=$ najmanjša $)$ & 3 & 2 & 1 \\
\hline Raznolikost dolinskih odsekov $(1=$ največja $)$ & 2 & 3 & 1 \\
\hline Hitrost menjavanja različnih dolinskih odsekov $(1=$ največja $)$ & 2 & 3 & 1 \\
\hline Razčlenjenost dolinskega dna $(1=$ največja $)$ & 2 & 3 & 1 \\
\hline Razčlenjenost rečne struge $(1=$ največja $)$ & 2 & 3 & 1 \\
\hline Velikost prodišč (1 = največja $)$ & 2 & 1 & 3 \\
\hline Slikovitost menjavanja prodišč in vodnih površin $(1=$ največja $)$ & 2 & 3 & 1 \\
\hline Množina vode poleti $(1=$ največja $)$ & 3 & 2 & 1 \\
\hline Čistost vode $(1=$ najčistejša $)$ & 3 & 2 & 1 \\
\hline Zaraščenost rečnih bregov $(1=$ najmanjša $)$ & 2 & 3 & 1 \\
\hline Sukcesija zaraščanja prodišč $(1=$ najizrazitejša $)$ & 3 & 2 & 1 \\
\hline Naravnost vodnega toka $(1$ = največja $)$ & 3 & 2 & 1 \\
\hline Naravnost toka drobirja $(1=$ največja $)$ & 3 & 2 & 1 \\
\hline Intenzivnost toka drobirja $(1=$ največja $)$ & 3 & 1 & 2 \\
\hline Antropogeni posegi v rečno strugo ( 1 = najmanjši $)$ & 3 & 2 & 1 \\
\hline Varnost zadrževanja v strugi -- nihanje pretoka $(1=$ najvarneje $)$ & 3 & 2 & 1 \\
\hline Možnosti za vodne športe (1 = največja) & 2 & 3 & 1 \\
\hline Možnosti za kopanje (1 = največja) & 3 & 2 & 1 \\
\hline Možnosti za športni ribolov (1 = največje $)$ & 3 & 2 & 1 \\
\hline Vključenost reke v turistično ponudbo $(1=$ največja $)$ & 2 & 3 & 1 \\
\hline
\end{tabular}

\section{POLOŽAJ SOČE V ŠIRŠEM GEOGRAFSKEM PROSTORU}

Geografski položaj območja ob Soči v širšem južnoalpskem prostoru je ključnega pomena za razmišljanje o nadaljnjem sonaravnem razvoju. To seveda ne pomeni konzerviranje, ampak s širšo okolico povezan razvoj, ki bistveno ne prizadene naravnih procesov in ne izčrpava ali uničuje obstoječih naravnih virov, a hkrati ponuja prebivalcem možnosti za vsestranski gospodarski in družbeni razvoj. 
Geopolitični položaj Zgornjega Posočja se je v novejši zgodovini močno spreminjal, na možnosti njegovega nadaljnjega razvoja pa je zanimivo gledati z vidika obeh sosednjih držav, Italije in Slovenije.

Gorski svet Furlanije-Julijske krajine in Benečije je izrazito periferno območje Italije, ki je daleč stran od Rima kot središča odločanja in ga je Italija dobila šele $\mathrm{z}$ dunajskim mirom oktobra 1866. Njegovo obrobnost je po drugi svetovni vojni okrepila še obmejna lega ob južnem delu železne zavese na jugoslovansko-italijanski meji.

Ta izrazita obrobnost se kaže predvsem v naslednjih dveh vidikih:

1. Odseljevanje prebivalstva in s tem povezano propadanje gorske kulturne pokrajine je bilo skoraj $\mathrm{v}$ celoti prepuščeno stihiji in je na obsežnih območjih pomenilo dokončno depopulacijo, hkrati pa kritično poslabšalo položaj furlanske narodne manjšine v alpskem delu Furlanije ter slovenske v Kanalski dolini, v zahodnih Julijskih Alpah in v Beneški Sloveniji (Guidi--Piussi, 1993).

Rezultat tega, v bistvu naravnega procesa 'regeneriranja' je degradirana, večinoma $\mathrm{z}$ grmičjem poraščena pokrajina. Bivanje in gibanje $v$ takšni zapuščeni pokrajini sta za povprečnega človeka nezanimiva, povezana tudi s številnimi neprijetnostmi (zarasle poti, trnje, robidovje, plazilci, žuželke) in nevarnostmi (požari, uničene poti idr.), po drugi strani pa ni pričakovati nobenega zanimanja nosilcev odločanja, naravovarstvenikov in širše javnosti za varovanje takšnih območij, saj je v vsej Italiji veliko privlačnejših, varovanja še bolj potrebnih območij (Bätzing, 1990, 14).

2. Ker v italijanskih Alpah po drugi svetovni vojni ni bilo veliko domačega kapitala, je kapital skoraj v celoti prihajal iz gospodarsko razvite Padske nižine in ni kazal zanimanja za trajnejši ekološki, kulturni in gospodarski razvoj alpskih pokrajin, temveč je imel praviloma le kratkoročne gospodarske cilje (Bätzing, 1990, 74). Usmeril se je predvsem $\mathrm{v}$ gradnjo velikih zimskošportnih središč $\mathrm{v}$ visokogorskem delu Zahodnih Alp, v Južnih apneniških Alpah pa predvsem v Dolomitih, in $\mathrm{v}$ gradnjo hidroelektrarn za pridobivanje vršne energije, ne da bi pri tem upošteval koristi ali želje domačega prebivalstva.

Hudourniške vode Tilmenta $\mathrm{z}$ zelo močnim tokom drobirja so sicer oteževale izgradnjo hidroelektrarn, vendar so tudi njegove vode po letu 1927 uporabili za pridobivanje električne energije. Med obema svetovnima vojnama je 'na novo pridobljenem ozemlju prišla na vrsto tudi Soča, najprej $\mathrm{V}$ srednjem toku $\mathrm{S}$ hidroelektrarnama Plave in Doblar, nato pa bi se gradnja nadaljevala tudi v zgornjem toku (Melik, 1954, 257--258).

Na obrobnost gorskega sveta Furlanije-Julijske krajine kaže tudi dejstvo, da je tu zelo malo zavarovanih območij (med drugim 1990 ustanovljen regijski park Karnijske Predalpe, 25.874 ha), medtem ko jih je v podobnem gorskem svetu v Piemontu kar 54 (Bätzing, 1990, 36).

Zamujene priložnosti drugačnega razvoja $\mathrm{v}$ porečju Piave in Tilmenta pomenijo po eni strani veliko razvojno prednost Zgornjega Posočja, saj tu degradacijski procesi v kulturni pokrajini še niso tako napredovali, po drugi pa je to lahko možnost za vdor agresivnega italijanskega kapitala, ki ga bodo prej ali slej zamikale velike 
'neizkoriščene' razvojne možnosti alpske pokrajine na slovenski strani meje, saj "... zaraščanje kulturne pokrajine stopnjuje pritiske na ostala območja ..." (Plut, 1997, 40).

Tudi z vidika Slovenije je pokrajina ob zgornjem in srednjem toku Soče izrazito periferna, zaradi slabih prometnih povezav težko dostopna in odmaknjena. Obrobna lega Zgornjega Posočja je najbolj razvidna iz primerjave med severno in južno stranjo Julijskih Alp, gospodarsko razvitim zgornjim delom Gorenjske in nerazvitim Zgornjim Posočjem, ki jo je že pred 20 leti napravil S. Ilešič (1978). Razlike so deloma posledica naravnih razmer, predvsem pa različnega zgodovinskega razvoja $\mathrm{V}$ 19. in 20. stoletju.

Posledice tega so bile velike razlike v gospodarski razvitosti obeh delov že pred prvo svetovno vojno. Celotno Posočje sta silovito prizadela vojna in dogajanje na soški fronti, v obdobju italijanske okupacije (1918--43) pa se je obrobnost pokrajine v okviru Italije samo še stopnjevala, hkrati pa se je nadaljevala depopulacija, tako da pokrajina takrat dejansko ni imela nikakršnih razvojnih možnosti, razen za pridobivanje električne energije.

Ko je Zgornje Posočje 1945 prišlo v Jugoslavijo, se njegov marginalni položaj ni bistveno popravil. Kljub temu da je $\mathrm{v}$ to obmejno območje prišlo nekaj novih gospodarskih dejavnosti, se je depopulacija nadaljevala vse do današnjih dni, posebno v visokogorskem delu. V okviru nove komunalne ureditve je bila leta 1961 ukinjena še občina $\mathrm{v}$ Bovcu, tako da se je težišče gospodarskega in družbenega razvoja skoraj v celoti prestavilo v Tolmin kot novo regionalno središče. Podobno kot Piava in Tilment je bil zgornji del soške doline najprej predviden za pridobivanje električne energije (hidroelektrarni Trnovo in Kobarid), kar je sprožilo dolgotrajne polemike med zagovorniki varovanja Soče in energetske rabe, kasneje pa je prevladala zamisel o Zgornjem Posočju kot rekreacijskem in naravovarstvenem 'rezervatu' za ostalo, gospodarsko razvitejšo Slovenijo.

\section{MOŽNOSTI NADALJNJEGA SONARAVNEGA RAZVOJA ZGORNJEGA POSOČJA}

Tudi po osamosvojitvi Slovenije ostaja Zgornje Posočje gospodarsko manj razvit, prometno težko dostopen del Slovenije ob njeni zahodni meji, čeprav so se v teh nekaj letih že pokazale nekatere spremembe na bolje. Predvsem velja poudariti novo gledanje na Sočo kot najpomembnejši naravni vir celotne pokrajine, ki bi lahko bil eden od temeljev nadaljnjega sonaravnega razvoja. Nova država se počasi začenja zavedati negativnih posledic propadanja gorskih in obmejnih območij in mogoče lahko v tem smislu kot pozitivno ocenimo tudi širokopotezno zastavljeno popotresno 
obnovo, čeprav bo na pozitivne učinke treba še počakati, saj je več kot stoletje dolgo, neprekinjeno depopulacijo izjemno težko zaustaviti.

Ob nekaterih naštetih pozitivnih premikih v odnosu Slovenije do Zgornjega Posočja pa še vedno ostajajo navzoči tudi ostali, parcialni pogledi na to pokrajino, predvsem:

1. ohraniti Zgornje Posočje kot rekreacijsko območje za gospodarsko razvitejši del Slovenije,

2. izrabiti velik vodni potencial Soče in pritokov za pridobivanje električne energije (male hidroelektrarne, HE Učja), četudi gradnja hidroelektrarne na zgornjem toku Soče trenutno morda ni več aktualna,

3. ohraniti planinsko pašništvo zgolj kot etnološko svojevrsten del turistične ponudbe Zgornjega Posočja in ne kot, s pomočjo državnih subvencij, uspešno gospodarsko dejavnost.

Drugi ključni vidik ohranjanja možnosti nadaljnjega sonaravnega razvoja Zgornjega Posočja je nujnost zavarovanja Soče kot naravnega spomenika najvišjega reda, saj kljub deklarativnemu izrekanju za varovanje izrazito prevladuje koristolovstvo (primer gradnje hidroelektrarne Krajcarca v Triglavskem narodnem parku).

Spremenjene družbene in gospodarske razmere, predvsem uvajanje tržnega gospodarstva in zasebnega kapitala, ter koncentracija politične in gospodarske moči v glavnem mestu in gospodarsko razvitejših delih še povečujejo populacijski, infrastrukturni in kapitalski primanjkljaj Zgornjega Posočja. Naraščanje razlik v razvitosti Zgornjega Posočja in drugih slovenskih regij lahko sproži stihijski dotok kapitala iz drugih območij Slovenije, ki bi bil za Zgornje Posočje po nastanku in nosilcih odločanja 'tuj' in bi se v primeru odsotnosti varovalnih mehanizmov obnašal povsem 'neslovensko', podobno kot italijanski kapital v italijanskem delu Južnih apneniških Alp. Temu kapitalu se lahko vsak hip pridruži še italijanski in drugi kapital, še zlasti po vključitvi Slovenije v Evropsko zvezo.

Sprijazniti se moramo z dejstvom, da si tudi zavoljo pravice domačega prebivalstva in posoških občin do gmotnih koristi od sonaravne rabe reke Soče ne moremo privoščiti njene popolne zaščite pred vsakršnimi posegi. Številni tuji primeri kažejo, da je tudi ob zelo ostrih varstvenih ukrepih možno pridobivati dobiček, še več, edino strogi varstveni ukrepi in njihovo dosledno upoštevanje lahko preprečijo razvrednotenje naravnega vira in zagotovijo naravi ter ljudem trajne možnosti nadaljnjega razvoja.

Kot kažeta usodi Piave in Tilmenta, je vsakršnega sonaravnega razvoja konec v tistem trenutku, ko naravni vir prepustimo dejavnosti, ki s popolno, izključujočo rabo izloči vse ostale možne uporabnike. $\mathrm{V}$ primeru Piave in Tilmenta je to elektrogospodarstvo, v Železni dolini med Tabljo (Pontebba) in izlivom Bele v Tilment pa promet. Če se bodo koncesije za uporabo reke Soče razdeljevale brez učinkovitih mehanizmov celovitega varovanja, bi se podobno lahko zgodilo tudi na Soči, npr. s pretiranim razvojem množičnega turizma. In potem, ko bi bilo že bolj ali manj prepozno, bi se moralo uveljavljanje sonaravnega razvoja, podobno kot na večini alpskih rek, zadovoljiti z iskanjem odsekov v kolikor toliko naravnem stanju, ki bi jih bilo še možno ali vredno zavarovati, ali z zelo dragim odpravljanjem napak (t.i. renaturacija), čemur bi se lahko ob drugačnem pristopu izognili. 
Tretja, doslej prezrta značilnost Zgornjega Posočja, ki je zelo pomembna za razmišljanje o možnostih nadaljnjega sonaravnega razvoja, je izjemna prilagojenost človeka hudourniški naravi Soče in njenih pritokov. Čeprav dobi Zgornje Posočje ponekod tudi več kot $3000 \mathrm{~mm}$ padavin in se lahko zaradi njihove intenzivnosti pretok Soče v nekaj urah poveča za stokrat ali več, celotno porečje Soče ni posebno ogroženo zaradi poplav. Glavni razlog je v pogostnosti visokih vod, tako da jim je prilagojena tako zmogljivost rečne struge za pretok velikih množin vode in kamninskega drobirja, kot tudi domačini, ki so si na podlagi izkušenj pridobili 'občutek za distanco' in s svojimi dejavnostmi ostali v varni oddaljenosti od reke. Zaradi tega teče Soča še danes po skoraj povsem naravni strugi in ima dovolj prostora za odtok tudi ob najvišjih pretokih, vasi pa so brez izjeme nameščene na terasah ali vršajih, v varni oddaljenosti od sicer lepe, toda ob visoki vodi zelo nevarne hudourniške reke.

Tega občutka ne moremo pričakovati od lastnikov kapitala in prihodnjih iskalcev koncesij za gospodarsko rabo Soče, zaradi česar so za to dolžni poskrbeti država s svojimi vodnogospodarskimi in načrtovalskimi službami ter obsoške občine. Temeljna zahteva bi morala biti, da kakršne koli novogradnje ostanejo v dovolj varni oddaljenosti od reke in da se $\mathrm{v}$ strugo ter obvodni prostor posega le izjemoma (vzdrževanje vodnogospodarskih objektov, ureditev pristopov k reki). Sicer ne bo mogoče trajno zagotoviti niti varnega bivanja tako zaželjenih turistov (npr. kampi ob reki so zelo privlačni, vendar se ob nenadnih nalivih lahko hitro spremenijo $\mathrm{v}$ smrtnonosne pasti) niti normalnega delovanja rečnega sistema ob visoki vodi niti trajnostnega razvoja celotne pokrajine.

\begin{abstract}
SKLEP
Čeprav na splošno prevladuje mnenje o izjemni (enkratni) vrednosti Soče tako v slovenskem kot evropskem merilu, v Sloveniji ni posebno veliko ljudi, na katere bi se lahko oprla naravovarstvena prizadevanja za zaščito Soče in pokrajine ob njej. V tržnem gospodarstvu so nosilci odločanja pač hkrati tudi lastniki kapitala in s tem nosilci razvoja, ki z gospodarskimi dejavnostmi ustvarjajo materialno podlago države. Nosilci prizadevanj za sonaravno rabo Soče bi morali biti, poleg strokovne javnosti in ljubiteljev narave, predvsem domačini in njihove lokalne skupnosti, ki bi jim morala država z različnimi mehanizmi (zakonodaja, podeljevanje koncesij, pomoč iz proračunskih sredstev) pomagati, da se v precepu med lastnimi potrebami po razvoju, koristi lastnikov kapitala in naravnovarstvenimi prizadevanji $\mathrm{v}$ skladu $\mathrm{z}$ načeli sonaravnega razvoja odločijo za takšne načine rabe Soče, ki ne bodo prizadeli koristi njihovih potomcev. To nalogo pa bodo lahko opravljali le, dokler bodo živeli $\mathrm{v}$
\end{abstract}


pokrajini in svojih občinah, zaradi tega pa bi morala država tudi pomagati zaustaviti propadanje kulturne pokrajine.

Za razreševanje navideznega konflikta med enimi, ki bi 'radi sprostili velike razvojne možnosti Zgornjega Posočja', in drugimi, ki 'se nerazumno upirajo vsakršnemu napredku' (t. j. naravovarstveniki), je nujno potrebna celovita zakonska zaščita Soče. Enako pomembno pa je prepričati javnost, da je strogo zakonsko varovanje Soče temeljni pogoj za njen trajnostni razvoj in ne zavora 'prizadevanjem za napredek pokrajine'.

\section{LITERATURA}

1. Bätzing W., 1990: Der italienische Alpenraum. Eine Analyse der aktuellen Probleme in Hinblick auf die Alpen-Konvention. CIPRA Petite Serie documentaire 7/90, 92 str. Vaduz.

2. Enciclopedia monografica del Friuli Venezia Giulia, 1. in 2. del. 497 str. Udine 1971.

3. Guidi M., Piussi P., 1993: Natural afforestation and landscape changes in the Eastern Prealps of Italy. Révue de géographie alpine, let. 81, št. 3, 95--102.

4. Ilešič S., 1978: Pomen kompleksnega regionalnega aspekta v sodobni geografiji na primeru alpskih predelov Slovenije. Zgornje Posočje. Zbornik 10. zborovanja slovenskih geografov, Tolmin-Bovec, 26.--28. IX. 1975, 35--43.

5. Natek K., 1995: Splošna oznaka zgornjega dela Posočja z vlogo naravnega spomenika Soče v njem. Tipkopis. 51 str. Ljubljana.

6. Plut D., 1997: Slovenia and its adapting to European processes of sustainable development. Hrvatski geografski glasnik 59, 35--47. 


\title{
THE POSSIBILITIES OF SUSTAINABLE DEVELOPMENT IN THE RIVER BASINS OF THE THREE ADJACENT SOUTHERN ALPINE RIVERS: PIAVE, TAGLIAMENTO AND SOČA
}

\begin{abstract}
Summary
The upper part of the Soča river basin remains a peripheral and less developed part of Slovenia along its western border with Italy. The partial approaches to its future development are still present (namely, to preserve the valley as the recreational area for the more developed parts of Slovenia, to use the hydro power of the Soča River for the production of electricity, or to preserve the villages in the valley and alps in the mountains as a part of ethnological heritage for tourists only) but, the new notion of the key importance of the Soča River as the main natural resource of the whole region is also getting stronger.

To achieve the long-term goal of sustainable development, the process of depopulation of the Soča river basin should be mitigated or even stopped, an effective legal protection of the Soča River applied in order to avoid the negative effects of the further inflow of capital, and to prevent any unnecessary interventions into the river bed or adjacent area. Of the same importance is to find the way how to preserve the existing cultural landscape and to retain the economic base of people living in the area. Without the native population as the main carrier of future development and with no improvement of existing communications with the rest of Slovenia there is no future for sustainable development, only the accelerated process of renaturation, i.e. extinction of human presence.

The situation in the similar valleys of the Piave and Tagliamento rivers in Italy shows very clearly the negative consequences of unilateral use of the rivers for the production of electricity on the whole area. Unlimited use of the Soča River for the recreation and mass tourism could have similar irreversible consequences for the whole valley if the utilisation of the river will not be based on effective mechanisms of nature protection and well considered allocations of concessions for the sustainable use of the river. These questions should be considered very carefully to avoid any fatal error, because we all are responsible to preserve the last southern alpine natural river for the future generations. From the physico-geographical point of view, it is the most important to stay with the buildings and other installations out of the reach of torrential waters of the Soča River, which will always ruthlessly take the necessary space for the violent flow of flood waters and large amount of debris.
\end{abstract}

